\title{
Analysis of the use of technical means for rehabilitation of patients with spastic types of cerebral palsy depending on the level of patient' motor function
}

\author{
E.I. Dzhomardly, A.A. Koltsov
}

Federal Scientific Center of Rehabilitation of the Disabled named after G.A. Albrecht, Saint Petersburg, Russian Federation

\begin{abstract}
Introduction Spastic types of cerebral palsy are around $80 \%$ of all CP cases diagnosed. They feature early secondary orthopedic complications, for the prevention of which, within the framework of comprehensive rehabilitation treatment, technical means of rehabilitation (TMR) have been widely used, and first of all, individual and model orthoses. Currently, there are no clear indications for their application. Aim To determine the variants of orthoses and their distribution depending on the level of motor activity of patients with spastic types of cerebral palsy according to the GMFCS classification. Materials and methods A retrospective analysis of 662 patients with spastic types of cerebral palsy aged from two to 17 years for the period from 2007 to 2017 was conducted. All the patients were divided into 5 groups according to the levels of motor activity by GMFCS classification. Statistical data processing was performed using Statistica 10 and Excel software packages. Results Analysis showed that patients used 15 TMR types, of which 14 were orthoses of different designs. Inter-group differences in the spectrum of applied TMR were statistically confirmed. Statistically significant differences were found in pairwise comparison of all groups of patients with at least one type of means; maximum differences in 8 types of TMR were found in pairs of groups GMFCS 2 and 4, and GMFCS 2 and 5. Conclusion Technical means of rehabilitation are widely used by patients with spastic types of cerebral palsy for complex medical rehabilitation. The variability of the number and scope of TMR was found and depended on the level of motor activity. Given the above, it is important to further study the role of technical means in the medical rehabilitation of patients with cerebral palsy, including the development of guidelines for their application.

Keywords: cerebral palsy, orthoses, spasticity, contractures, level of motor activity, rehabilitation, GMFCS, technical means of rehabilitation
\end{abstract}

\section{INTRODUCTION}

The incidence of cerebral palsy (CP), according to the latest world literature, is from two to 3 children per 1,000 newborns [1-3]. Spastic types of the disease occur in at least $80 \%$ of all patients and are characterized by early development of secondary orthopedic complications, including contractures and deformities [4-6]. Given the severity, multiplicity and tendency to progression of these complications, early and regular orthopaedic monitoring is an important component of the comprehensive medical rehabilitation of CP children [7], which enables prevention or timely correction of deformities and motor disorders. One of the essential components of the orthopedic management of children with disabilities due to spastic types of cerebral palsy is technical means of rehabilitation (TMR) and, in particular, orthoses.

A wide range of available TMR, especially given the complex nature of the pathology and the variety of clinical manifestations, makes the choice difficult for a clinician. The analysis of the use of TMR and, in particular, of individual or standard orthoses, the determination of the principles of use and, as a result, the development of an algorithm for TMR indication is a relevant task.

The purpose of the study was to determine the options of technical means used for rehabilitation, primarily individual and standard orthoses, in patients with spastic types of cerebral palsy and their dependence on the level of motor activity according to the GMFCS classification.

\section{MATERIAL AND METHODS}

Medical histories of 662 patients with spastic CP types, aged from two to 17 years, who were treated at the hospital of the Federal Albrecht Scientific Centre for Rehabilitation of the Disabled Children between 2007 and 2017 were retrospectively analysed. Statistical analysis was conducted for 596 patients as

Dzhomardly E.I., Koltsov A.A. Analysis of the use of technical means for rehabilitation of patients with spastic types of cerebral palsy depending on the level of patient' motor function. Genij Ortopedii, 2020, vol. 26, no 1, pp. 57-64. DOI 10.18019/1028-44272020-26-1-57-64. (In Russian) 
the information on TMR of 93 patients was unavailable in their medical records. The disabled children were enrolled into five groups according to Gross Motor Function Classification System (GMFCS) [8-10].

Statistical analysis of quantitative findings was conducted with the non-parametric Kruskal-Wallis test. To describe the quantitative indicators, the mean value and standard deviation "M $\pm \mathrm{S}$ " were calculated. On all diagrams of quantitative variables, the arithmetic mean is indicated by a dot, the median is indicated by a horizontal segment, the intraquartile range is indicated by a rectangle, the minimum and maximum values are indicated by vertical segments. The statistical significance of various values for binary and nominal indicators was determined using the Chisquare Pearson criterion. Statistical significance is fixed at the error probability level $\mathrm{p}<0.05$. Statistical data processing was performed using Statistica 10 and Excel application software packages.

The study was approved by the ethics board of the institution and conducted in accordance with the ethical standards set forth in the Helsinki Declaration.

\section{RESULTS}

Patients were ranked according to the severity of the disease into five GMFCS groups (Fig. 1).

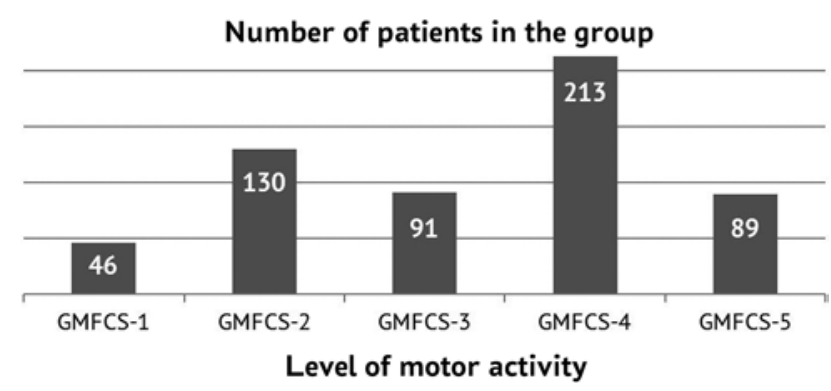

Fig. 1 Distribution of the patients according to the severity of the disease by GMFCS level

To determine the statistically significant difference in gender distribution in the groups, the Pearson Chi-square test was used. The result of this analysis showed that the distribution by gender was homogeneous $(\mathrm{p}=0.7973)$ (Table 1$)$.

To check the distribution of patients by age in the groups, the database was analyzed using the KruskalWallis test, and there was a minimal difference between the groups $(p=0.0402)$ (Fig. 2).

To identify the spectrum of the TMR used and their distribution by the levels of motor activity, a frequency analysis of the data was performed on the groups (Table 2).

The result of the frequency analysis of the patient database showed that 15 variants of TMRs were used (Fig. 3).

Separately, patients with predominantly GMFCS motor activity levels 4 and 5 were identified, in the medical records of which there was a lack of TMR. Their number (50 subjects, $8.4 \%$ ) was unexpectedly significant given the severity of motor impairment.

The leading place in the structure of the TMRs applied took various variants of braces for the lower limb (444 patients, $74.5 \%$ ) (Table 2), among which there was a predominance of the braces for the entire lower limb (Fig. 4). An ankle brace was used much less frequently, and a knee bracing was extremely rare. Patients of all the groups studied useв braces. Braces were used less commonly in patients with the GMFCS level 1. As the condition of children aggravated, an increase in the number of patients using braces of different designs was observed, with a maximum number in the GMFCS 4 group. In patients of the GMFCS level 5 group, ankle braces were used twice less. Analysis of the distribution of braces for the knee joint in groups was not relevant due to their small numbers.

According to the data in Table 2, high rates of using orthopedic shoes were noted (399 people, $67.0 \%)$. An analysis of the frequency of using orthopedic shoes showed a maximum in the GMFCS 2 group ( $86.9 \%$ ), and declined as the patients' motor activity impaired, with a minimum in patients with GMFCS 5 motor activity level (53.9\%) (Fig. 4).

Table 1

Patients' gender distribution

\begin{tabular}{|c|c|c|c|c|c|c|}
\hline & \multicolumn{5}{|c|}{ Level of motor activity } & $\begin{array}{l}\text { Pearson Chi-square test. } \\
\text { Level } \mathrm{p}(\mathrm{df}=4)\end{array}$ \\
\hline Gender & GMFCS 1 & GMFCS 2 & GMFCS 3 & GMFCS 4 & GMFCS 5 & \multirow{3}{*}{0.7973} \\
\hline Female & $22(47.8 \%)$ & $67(51.5 \%)$ & $42(46.2 \%)$ & $111(52.1 \%)$ & $41(46.1 \%)$ & \\
\hline Male & $24(52,2 \%)$ & $63(48,5 \%)$ & $49(53,8 \%)$ & $102(47,9 \%)$ & $48(53,9 \%)$ & \\
\hline
\end{tabular}


Genii Ortopedii, Vol. 26, no 1, 2020

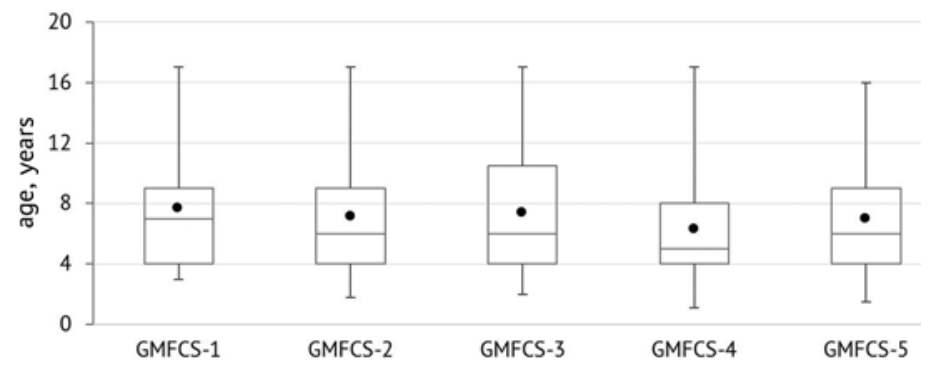

Fig. 2 Quartile charts: distribution of patients by age

Levels of motor activity (GMFCS)

Table 2

Frequency of TMR use in patients with spastic types of cerebral palsy according to GMFCS levels

\begin{tabular}{|l|c|c|c|c|c|c|}
\hline \multirow{2}{*}{ Variable (TMR) } & \multicolumn{5}{|c|}{ Levels of motor activity } & \multirow{2}{*}{ Total } \\
\cline { 2 - 6 } & $\begin{array}{c}\text { GMFCS 1 } \\
(\mathrm{n}=46)\end{array}$ & $\begin{array}{c}\text { GMFCS2 } \\
(\mathrm{n}=130)\end{array}$ & $\begin{array}{c}\text { GMFCS 3 } \\
(\mathrm{n}=91)\end{array}$ & $\begin{array}{c}\text { GMFCS 4 } \\
(\mathrm{n}=213)\end{array}$ & $\begin{array}{c}\text { GMFCS 5 } \\
(\mathrm{n}=89)\end{array}$ & \\
\hline No orthopaedic means & $4(8.7 \%)$ & $7(5.4 \%)$ & $3(3.3 \%)$ & $15(7.0 \%)$ & $21(23.6 \%)$ & 50 \\
\hline Orthopaedic shoes & $34(73.9 \%)$ & $113(86.9 \%)$ & $68(74.7 \%)$ & $136(63.8 \%)$ & $48(53.9 \%)$ & 399 \\
\hline Brace for ankle joint & $8(17.4 \%)$ & $24(18.5 \%)$ & $17(18.7 \%)$ & $40(18.8 \%)$ & $7(7.9 \%)$ & 96 \\
\hline Brace for knee joint & $2(4.3 \%)$ & $2(1.5 \%)$ & $5(5.5 \%)$ & $7(3.3 \%)$ & $0(0.0 \%)$ & 16 \\
\hline Brace for lower limb & $16(34.8 \%)$ & $55(42.3 \%)$ & $49(53.8 \%)$ & $133(62.4 \%)$ & $50(56.2 \%)$ & 303 \\
\hline Apparatus for ankle joint & $0(0.0 \%)$ & $8(6.2 \%)$ & $7(7.7 \%)$ & $9(4.2 \%)$ & $2(2.2 \%)$ & 26 \\
\hline Apparatus for the lower limb & $3(6.5 \%)$ & $11(8.5 \%)$ & $22(24.2 \%)$ & $44(20.7 \%)$ & $17(19.1 \%)$ & 97 \\
\hline $\begin{array}{l}\text { Apparatus for the lower limb } \\
\text { and trunk }\end{array}$ & $0(0.0 \%)$ & $0(0.0 \%)$ & $5(5.5 \%)$ & $23(10.8 \%)$ & $11(12.4 \%)$ & 39 \\
\hline Apparatus for hip joint & $2(4.3 \%)$ & $3(2.3 \%)$ & $10(11.0 \%)$ & $36(16.9 \%)$ & $7(7.9 \%)$ & 58 \\
\hline Brace for upper limb & $3(6.5 \%)$ & $2(1.5 \%)$ & $1(1.1 \%)$ & $1(0.5 \%)$ & $3(3.4 \%)$ & 10 \\
\hline Brace for wrist joint & $1(2.2 \%)$ & $1(0.8 \%)$ & $0(0.0 \%)$ & $0(0.0 \%)$ & $0(0.0 \%)$ & 2 \\
\hline $\begin{array}{l}\text { Semi-rigid brace and/or } \\
\text { reclinator }\end{array}$ & $3(6.5 \%)$ & $8(6.2 \%)$ & $17(18.7 \%)$ & $34(16.0 \%)$ & $17(19.1 \%)$ & 79 \\
\hline Rigid brace & $1(2.2 \%)$ & $1(0.8 \%)$ & $0(0.0 \%)$ & $1(0.5 \%)$ & $3(3.4 \%)$ & 6 \\
\hline Cheneau brace & $1(2.2 \%)$ & $1(0.8 \%)$ & $3(3.3 \%)$ & $5(2.3 \%)$ & $6(6.7 \%)$ & 16 \\
\hline Support for standing & $0(0.0 \%)$ & $0(0.0 \%)$ & $3(3.3 \%)$ & $22(10.3 \%)$ & $9(10.1 \%)$ & 34 \\
\hline Vilenski brace & $1(2.2 \%)$ & $2(1.5 \%)$ & $5(5.5 \%)$ & $18(8.5 \%)$ & $3(3.4 \%)$ & 29 \\
\hline
\end{tabular}

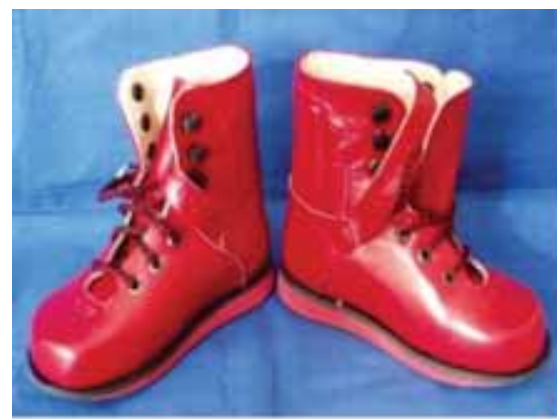

a

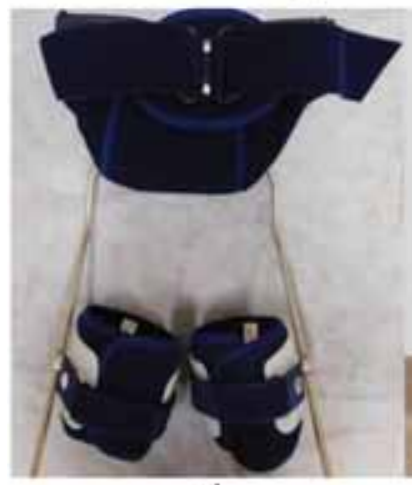

d

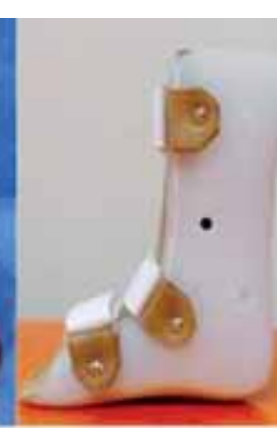

b c

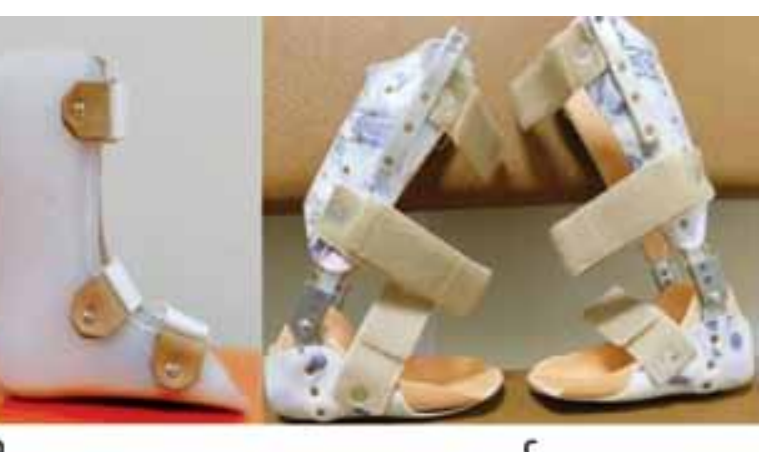

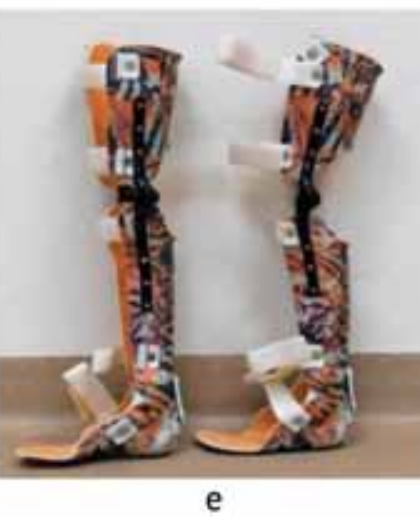

e

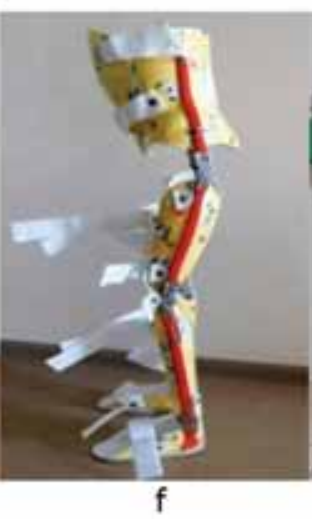

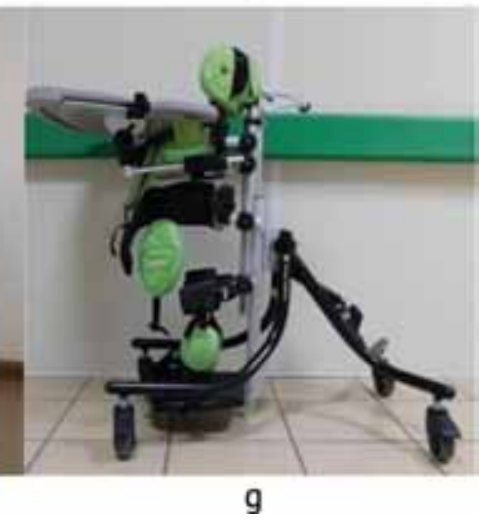

Fig. 3 TMR types: $\boldsymbol{a}$ - orthopedic shoes; $\boldsymbol{b}$ - brace for the ankle joint; $\boldsymbol{c}$ - apparatus for ankle joints; $\boldsymbol{d}$ - apparatus for the hip joints; $\boldsymbol{e}$ - apparatus for the entire lower limb; $\boldsymbol{f}$ - apparatus for the entire lower limb and trunk; $\boldsymbol{g}$ - support for standing verticalizer) 


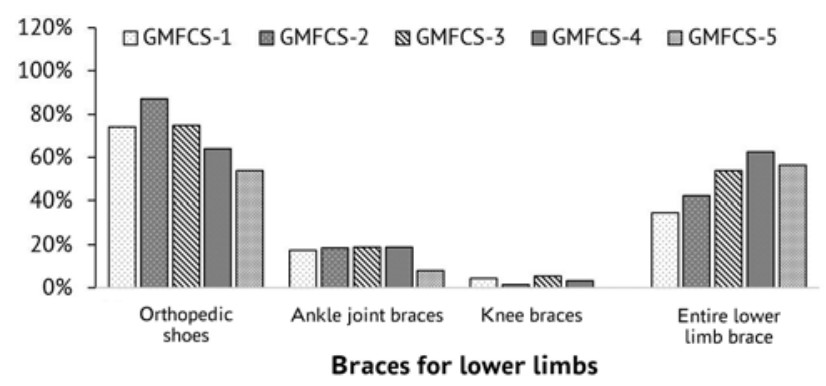

Fig. 4 Distribution and dynamics of changes in the braces and orthopedic shoes depending on the level of motor activity

A significant number of patients (220 patients, $36.9 \%$ ) used various designs of functional orthoses on the lower extremities or apparatuses of various designs (Table 2, Fig. 5). The apparatus most often used was for the entire lower limb (44.1\%), the most rarely used was the apparatus for the ankle joint $(11.8 \%)$. When analyzing the distribution of functional orthoses according to the severity of the patient's condition, it was revealed that the devices for the entire lower limb were used by patients of all groups with the maximum in the GMFCS 3 group and the minimum in the GMFCS 5 group. Hip joint devices were used by patients with any level of global motor dysfunction, but more frequently in groups of GMFCS 3-4. An analysis of the devices for the entire lower limb and trunk demonstrated the application of these orthoses for comprehensive rehabilitation of patients in GMFCS 3-5 groups with an increase in the rate of their use as motor activity decreased, with a maximum in the GMFCS level 5 group. Ankle devices were relevant for patients starting from the second level of motor activity, the highest rate of their use was GMFCS 3 group (7.7 \%), with a subsequent decrease as the limitations of motor activity and minimum in GMFCS group 5 (2.2\%).

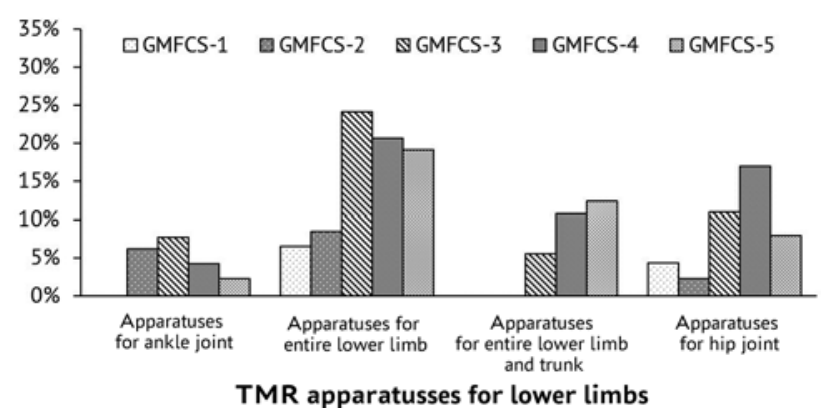

Fig. 5 Distribution and dynamics of changes in the spectrum of functional devices depending on the level of motor activity

According to the data presented in Table 2, the verticalizers (supports for standing) were used mainly by patients with levels of motor activity GMFCS 3 to 5 (3.3-10.3 \%). An extremely low use of orthoses for the upper limbs was noted, which primarily included braces for the entire upper limb (10 patients, $1.7 \%$ ), and braces for the wrist joint in separate patients (2 patients).

Orthoses on the trunk were a semi-rigid brace and/or a reclinator (79 patients, $13.3 \%$ ), less often a functional correction brace of the Cheneau type (16 patients, $2.7 \%$ ); rigid fixation braces were rarely used.

In order to statistically confirm the above data on the relationship between the levels of motor activity and the spectrum of the TMRs used, a pairwise comparison was performed, for which the Chi-square Pearson method was used which demonstrated intergroup differences (Table 3).

Table 3

Group Difference Analysis Results (Pearson Chi-Square Method with GMFCS Grouping Variable)

\begin{tabular}{|c|c|c|c|c|c|c|c|c|c|c|}
\hline \multirow[b]{2}{*}{ Variables (TMR) } & \multicolumn{10}{|c|}{ Multiple pair comparison, $p$ level } \\
\hline & \begin{tabular}{|l|} 
GMFCS-1 - \\
GMFCS-2 \\
\end{tabular} & $\begin{array}{c}\text { GMFCS-1 - } \\
\text { GMFCS-3 }\end{array}$ & $\begin{array}{c}\text { GMFCS-1 - } \\
\text { GMFCS-4 }\end{array}$ & $\begin{array}{c}\text { GMFCS-1 - } \\
\text { GMFCS-5 }\end{array}$ & $\begin{array}{c}\text { GMFCS-2 - } \\
\text { GMFCS-3 }\end{array}$ & \begin{tabular}{|c|} 
GMFCS-2 - \\
GMFCS-4 \\
\end{tabular} & \begin{tabular}{|c|} 
GMFCS-2 - \\
GMFCS-5 \\
\end{tabular} & \begin{tabular}{|c|} 
GMFCS-3- \\
GMFCS-4 \\
\end{tabular} & $\begin{array}{l}\text { GMFCS-3 - } \\
\text { GMFCS-5 }\end{array}$ & $\begin{array}{l}\text { GMFCS-4 - } \\
\text { GMFCS-5 }\end{array}$ \\
\hline No orthopaedic means & 0.4253 & 0.1753 & 0.6965 & 0.0347 & 0.4624 & 0.5433 & $<0.0001$ & 0.2051 & $<0.0001$ & $<0.0001$ \\
\hline Orthopaedic shoes & 0.0409 & 0.918 & 0.1925 & 0.0242 & 0.0205 & $<0.0001$ & $<0.0001$ & 0.0646 & 0.0036 & 0.1073 \\
\hline Brace for ankle joint & 0.8715 & 0.8535 & 0.8261 & 0.0951 & 0.967 & 0.9416 & 0.0271 & 0.984 & 0.0328 & 0.0171 \\
\hline Brace for knee joint & 0.2719 & 0.7735 & 0.7215 & 0.0475 & 0.0984 & 0.3258 & 0.2398 & 0.3652 & 0.0249 & 0.0836 \\
\hline Brace for lower limb & 0.3713 & 0.0348 & 0.0006 & 0.0184 & 0.0908 & 0.0003 & 0.0436 & 0.1615 & 0.753 & 0.31 \\
\hline $\begin{array}{l}\text { Apparatus for ankle } \\
\text { joint }\end{array}$ & 0.0851 & 0.0535 & 0.1559 & 0.3057 & 0.6545 & 0.4247 & 0.1737 & 0.2151 & 0.0938 & 0.4028 \\
\hline $\begin{array}{l}\text { Apparatus for the lower } \\
\text { limb }\end{array}$ & 0.676 & 0.0115 & 0.0241 & 0.0512 & 0.0013 & 0.0028 & 0.0206 & 0.4956 & 0.4087 & 0.7588 \\
\hline $\begin{array}{l}\text { Apparatus for the lower } \\
\text { limb and trunk }\end{array}$ & 1 & 0.1053 & 0.0196 & 0.0128 & 0.0069 & 0.0001 & $<0.0001$ & 0.1431 & 0.1056 & 0.6955 \\
\hline Apparatus for hip joint & 0.4741 & 0.1941 & 0.0291 & 0.4374 & 0.0069 & $<0.0001$ & 0.053 & 0.1877 & 0.4737 & 0.0405 \\
\hline Brace for upper limb & 0.0804 & 0.075 & 0.0025 & 0.3998 & 0.7811 & 0.3023 & 0.3726 & 0.5342 & 0.3012 & 0.0444 \\
\hline Brace for wrist joint & 0.4398 & 0.158 & 0.0311 & 0.1627 & 0.4017 & 0.1999 & 0.4069 & 1 & 1 & 1 \\
\hline Brace reclinator & 0.9294 & 0.057 & 0.097 & 0.0512 & 0.0038 & 0.0072 & 0.0031 & 0.5612 & 0.9426 & 0.5068 \\
\hline $\begin{array}{l}\text { Semi-rigid brace and/or } \\
\text { reclinator }\end{array}$ & 0.4398 & 0.158 & 0.2311 & 0.6975 & 0.4017 & 0.7235 & 0.1579 & 0.5127 & 0.0774 & 0.0444 \\
\hline Cheneau brace & 0.4398 & 0.7124 & 0.9434 & 0.2566 & 0.1654 & 0.2794 & 0.0136 & 0.6358 & 0.289 & 0.0631 \\
\hline Support for standing & 1 & 0.2131 & 0.0227 & 0.0256 & 0.0371 & 0.0002 & 0.0002 & 0.041 & 0.0668 & 0.955 \\
\hline Vilenski brace & 0.7748 & 0.3698 & 0.1387 & 0.6975 & 0.0984 & 0.008 & 0.3726 & 0.3721 & 0.4894 & 0.1136 \\
\hline
\end{tabular}


Table 3 shows that statistically significant differences $(p<0.05)$ were revealed in the following pairs compared with the maximum differences: "GMFCS 1 - GMFCS 4"; "GMFCS 1 - GMFCS 5"; "GMFCS 2 -GMFCS 3"; “GMFCS 2 - GMFCS 4";
"GMFCS 2 - GMFCS 5". Thus, a significant increase in intergroup differences in the number and variants of used TMRs was noted with an increase in the severity of motor disorders.

\section{DISCUSSION}

A retrospective study showed the widespread use of technical means of rehabilitation in the complex treatment of children with spastic types of cerebral palsy with all GMFCS levels. None of technical means of rehabilitation was reported in $8.4 \%$ of patients, mainly with levels of motor activity GMFCS 4 and 5; given the prevalence of cerebral palsy, the number of such children was unexpectedly high. The reasons for this phenomenon, from our point of view, include factors such as insufficient awareness of parents or legal representatives about the need/ possibility of using TMRs; difficulties in obtaining funding for the manufacture of orthoses; untimely visits of patients to specialists such as a neurologist or orthopaedic traumatologist; refusal to use technical means of rehabilitation due to an extremely negative reaction of the child due to the severity of his/her condition or incorrect indications, manufacture or fitting of products.

The paucity of scientific publications devoted to the study of the TMR role in the medical rehabilitation of patients with cerebral palsy, and, as a result, the lack of clinical recommendations, lead to insufficient awareness of primary care medical personnel who are faced with such a problem. We found publications, primarily in foreign periodicals, devoted to the study of the effects of certain types of orthoses, but we did not find any work containing a statistical analysis of the frequency of their use and the entire spectrum of TMRs used [11].

Frequency analysis of the distribution of orthoses showed that braces of various designs were most often used on the lower extremities, among which there was a significant predominance of braces used "on the entire limb"(68.2\%). The result is consistent with the views of a number of foreign researchers (G. Molenaers et al., 2001; JR Gage, 2004; K. Desloovere et al., 2007), reporting the widespread use of braces in complex medical rehabilitation of patients, despite the lack of evidence [12-14]. Our analysis of the literature, conducted with the keywords in the search engines PEDro, Scopus, PubMed, eLibrary, also showed that the efficiency of this type of orthosis in children with spastic types of cerebral palsy was little investigated. The first report on the efficacy of an ankle brace is attributed to C. Tardieu et al. [15], despite the limited design of their study (only 2 patients; lack of a control group, etc.). In a recent study by J.C. Maas et al. [16], an analysis of the effect of the entire lower limb splint is presented, both its separate use and in combination with devices on the ankle joint (66 patients).

High rates of orthopedic shoes use $(67.0 \%)$ in the groups of the patients studied is explained by the fact that pathological positions and deformities of the foot occur early and are the leading disorders of the musculoskeletal system in patients with spastic types of cerebral palsy [17-19]. At the same time, the study of the publications found showed a discrepancy between the rates of orthopaedic footwear use and its description in the literature. The available works are devoted to studying the footwear design features [20-21].

We did not find any clinical studies that objectively substantiate the need for orthopedic shoes in children with spastic types of cerebral palsy, including the effect of orthopaedic shoes on support and motion function, the factors that parents and/or children themselves first pay attention to. The uneven distribution of the using orthopaedic footwear in the groups, with a maximum in patients with GMFCS 2 level of motor activity, is due to the fact that patients with more severe disorders are characterized by multilevel lesions and rigidity of deformities of the locomotor apparatus, in order to prevent the development and correction of which functional orthoses are more often used, devices on the lower limb of various designs. The lowest use of orthopedic shoes in patients with GMFCS level 5 is associated primarily with the severity of the underlying disease and, as a consequence, a change in priorities in patient management. So, one of the main tasks of an orthopedic surgeon in the treatment of patients of this group is postural management aimed at correct 
orthopedic positioning, including verticalization of the patient and ensuring the possibility of a sitting position. To achieve these goals, supports for standing (verticalizers), supports for seating (orthopedic chairs, wheelchairs), etc. are used.

The analysis of the use of functional orthoses showed a clear prevalence of "high" devices (for the entire lower limb, on the lower limbs and the trunk), $44.1 \%$, and $17.8 \%$, respectively, especially in patients with significant impairments. The argumentation of specialists for indications of such orthoses is multi-level lesions in children of GMFCS 3-5 groups and, therefore, the need to gain the ability to control (fixation, defixation, stabilization, correction) at all levels due to the technical means used [22]. However, in both domestic and world literature, we did not find significant studies on the role of TMR in the management of patients with cerebral palsy. Moreover, our results clearly differ from the data presented in foreign literature, the majority of publications in which are devoted to the study of the efficacy of the use of orthoses for ankle joints of various designs (AFO, GRAFO, leaf-spring AFO, etc.) as the most used in clinical practice [23, 24].

The analysis of world literature over the past 10 years has revealed an increase in the number of publications devoted to the role of devices for hip joints ("Hip abductor brace/orthosis" "SWASH orthosis") in the management of patients with cerebral palsy. The high rate of using these devices in the structure of functional orthoses was also revealed by our study $(26.4 \%)$. The main subject in the foreign studies found was the effect of these orthoses on the condition of the hip joints both used when separately and in combination with surgical treatment and/or botulinum therapy [25-26]. There are practically no publications covering the effect of hip orthoses on the general statodynamic function, the stereotype of the patient's motion, while this aspect seems to us primary, taking into account such a common manifestation of spasticity as adduction or contracture of the joints of the lower extremities.

The results of this study on the use of verticalizers (supports for standing) are consistent with the world data. According to a number of foreign authors (RJ Palisano et al., 2009; S. Hill et al., 2009; TE Pountney et al., 2009), the use of verticalizers as an element of postural control is advisable in children with cerebral palsy with GMFCS levels of motor activity 4-5 [27-29]. According to J. Goodwin et al., despite the low evidence on the efficiency of verticalizers, their indication for patients with cerebral palsy with impaired GMFCS levels 4 and 5 as part of postural management is a common practice abroad (in particular in England) [ 3].

\section{CONCLUSION}

1. Technical means of rehabilitation have been widely for comprehensive medical rehabilitation of children with spastic types of cerebral palsy.

2. Rates and spectrum of the technical means of rehabilitation used depend on the patients' level of motor activity.

3. The main orthoses used in children with cerebral palsy are braces and devices for the lower extremities of various designs, orthopedic shoes.
4. Factors such as the absence of orthopedic supplies, the discrepancy between the data obtained by us on the use of certain types of orthoses and the world literature, the ambiguity of the results of previously published studies require further study of a prospective group of patients with the aim of developing an algorithm for prescribing rehabilitation means for children with spastic types of cerebral palsy.

\section{REFERENCES}

1. Armand S., Decoulon G., Bonnefoy-Mazure A. Gait analysis in children with cerebral palsy. EFORT Open Rev., 2016, vol. 1, no. 12 , pp. 448-460. DOI: 10.1302/2058-5241.1.000052.

2. Narayanan U.G. Lower Limb Deformity in Neuromuscular Disorders: Pathophysiology, Assessment, Goals, and Principles of Management. Sabharwal S., editor. Pediatric Lower Limb Deformities: principles and techniques of management. Cham, Springer, 2016, pp. 267-269. DOI: 10.1007/978-3-319-17097-8_17.

3. Goodwin J., Colver A., Basu A., Crombie S., Howel D., Parr J.R., McColl E., Kolehmainen N., Roberts A., Lecouturier J., Smith J., Miller K., Cadwgan J. Understanding frames: A UK survey of parents and professionals regarding the use of standing frames for children with cerebral palsy. Child Care Health Dev., 2018, vol. 44, no. 2, pp. 195-202. DOI 10.1111/cch.12505. 
4. Klochkova O.A., Kurenkov A.L., Kenis V.M. Formirovanie kontraktur pri spasticheskikh formakh detskogo tserebralnogo paralicha: voprosy patogeneza [Formation of contractures in spastic cerebral palsy: pathogenesis problems]. Ortopediia, Travmatologiia $i$ Vosstanovitelnaia Khirurgiia Detskogo Vozrasta, 2018, vol. 6, no. 1, pp. 58-66. (in Russian) DOI: 10.17816/PTORS6158-66.

5. Solopova I.A., Moshonkina T.R., Umnov V.V., Vissarionov S.V., Baindurashvili A.G., Gerasimenko Iu.P. Neiroreabilitatsiia patsientov s detskim tserebralnym paralichom [Neurorehabilitation of patients with cerebral palsy]. Fiziologiia Cheloveka, 2015, vol. 41, no. 4, pp. 123-131. (in Russian)

6. Rosa M.C.N., Roque A.G.G. Spasticity Effect in Cerebral Palsy Gait. Müller B., Wolf S., eds. Handbook of Human Motion. Cham, Springer, 2016, pp. 2-15. DOI.: 10.1007/978-3-319-30808-1.

7. Shchekolova N.B., Mudrova O.A., Koziukov V.G., Belokrylov N.M., Nenakhova Ia.V., Taskaev A.L. Kompleksnyi patogeneticheskii podkhod $\mathrm{k}$ neiroortopedicheskoi reabilitatsii detei s tserebralnym paralichom v razlichnye vozrastnye periody [Complex pathogenetic approach to neuroorthopedic rehabilitation of children with cerebral palsy in different age-related periods]. Voprosy Kurortologii, Fizioterapii i Lechebnoi Fizicheskoi Kultury, 2016, vol. 93, no. 1, pp. 30-36. (in Russian) DOI:10.17116/kurort2016130-36.

8. Palisano R., Rosenbaum P., Walter S., Russell D., Wood E., Galuppi B. Development and reliability of a system to classify gross motor function in children with cerebral palsy. Dev. Med. Child. Neurol., 1997, vol. 39, no. 4, pp. 214-223. DOI: 10.1111/j.14698749.1997.tb07414.x.

9. Hanna S.E., Bartlett D.J., Rivard L.M., Russell D.J. Reference curves for the Gross Motor Function Measure: percentiles for clinical description and tracking over time among children with cerebral palsy. Phys. Ther., 2008, vol. 88, no. 5, pp. 596-607. DOI: 10.2522/ ptj.20070314.

10.Rosenbaum P.L., Walter S.D., Hanna S.E., Palisano R.J., Russell D.J., Raina P., Wood E., Bartlett D.J., Galuppi B.E. Prognosis for gross motor function in cerebral palsy: creation of motor development curves. JAMA, 2002, vol. 288, no. 11, pp. 1357-1363. DOI: $10.1001 /$ jama.288.11.1357.

11.Tolentino J., Talente G. Cerebral Palsy. M. Pilapil, D.E. DeLaet, A.A. Kuo, C. Peacock, N. Sharma, editors. Care of Adults with Chronic Childhood Conditions: A Practical Guide. Switzerland, Springer International Publishing, 2016, pp. 67-86. DOI 10.1007/978-3319-43827-6.

12.Gage J.R. The Treatment of Gait Problems in Cerebral Palsy. London, Mac Keith, 2004, 423 p.

13.Desloovere K., Molenaers G., De Cat J., Pauwels P., Van Campenhout A., Ortibus E., Fabry G., De Cock P. Motor function following multilevel botulinum toxin type A treatment in children with cerebral palsy. Dev. Med. Child. Neurol., 2007, vol. 49, no. 1, pp. 56-61.

14.Molenaers G., Desloovere K., De Cat J., Jonkers I., De Borre L., Pauwels P., Nijs J., Fabry G., De Cock P. Single event multilevel botulinum toxin type A treatment and surgery: similarities and differences. Eur. J. Neurol., 2001, vol. 8, no. Suppl. 5, pp. 88-97.

15.Tardieu C., Lespargot A., Tabary C., Bret M.D. For how long must the soleus muscle be stretched each day to prevent contracture. Dev. Med. Child. Neurol., 1988, vol. 30, no. 1, pp. 3-10.

16.Maas J.C., Dallmeijer A.J., Huijing P.A., Brunstrom-Hernandez J.E., Van Kampen P.J., Jaspers R.T., Becher J.G. Splint: the efficacy of orthotic management in rest to prevent equinus in children with cerebral palsy, a randomised controlled trial. BMC Pediatr., 2012, vol. 12, pp. 38. DOI: 10.1186/1471-2431-12-38.

17.Galli M., Cimolin V., Pau M., Leban B., Brunner R., Albertini G. Foot pressure distribution in children with cerebral palsy while standing. Res. Dev. Disabil., 2015, vol. 41-42, pp. 52-57. DOI.:10.1016/j.ridd.2015.05.006.

18.Kedem P., Scher D.M. Foot deformities in children with cerebral palsy. Curr. Opin. Pediatr., 2015, vol. 27, no. 1, pp. 67-74. DOI: 10.1097/MOP.0000000000000180.

19.Kenis V.M. Lechenie dinamicheskikh ekvino-plano-valgusnykh deformatsii stop u detei s DTsP [Treatment of dynamic equinoplanovalgus foot deformities in children with CP]. Vestnik Severo-Zapadnogo Gosudarstvennogo Meditsinskogo Universiteta im. I.I. Mechnikova, 2012, vol. 4, no. 1, pp. 35-40. (in Russian)

20.Belova L.A., Bekk N.V., Zakhozhaia T.S., Belousova O.E., Tikhonova N.V. Tekhnologicheskie resheniia proektirovaniia ortopedicheskoi obuvi s uchetom biomekhaniki dvizhenii [Technological solutions for designing orthopedic shoes taking into account the biomechanics of movements]. Vestnik Tekhnologicheskogo Universiteta, 2015, vol. 18, no. 5, pp. 112-114. (in Russian)

21.Bekk N.V., Belova L.A., Lapina T.S. Features customization of orthopedic shoes for children with cerebral palsy. ISJ Theoretical \& Applied Science, 2018, vol. 12, no. 68, pp. 117-121. DOI: 10.15863/TAS.2018.12.68.21.

22.Spivak B.G., Vitenzon A.S. Protezno-ortopedicheskie izdeliia dlia detei s tserebralnymi paralichami [Orthopedic-prosthetic products for children with cerebral palsy]. Kratkie Tezisy dokladov Soveshchaniia-seminara po Organizatsii Protezno-ortopedicheskoi Pomoshchi Detiam [Brief Abstracts of the Seminar-meeting on Organization of Prosthetic-Orthopedic Care for Children]. L., 1978, pp. 34-37. (in Russian)

23.Wingstrand M., Hägglund G., Rodby-Bousquet E. Ankle-foot orthoses in children with cerebral palsy: a cross sectional based study of 2200 children. BMC Musculoskelet. Disord., 2014, vol. 15, pp. 327. DOI: 10.1186/1471-2474-15-327.

24.Morris C., Bowers R., Ross K., Stevens P., Phillips D. Orthotic management of cerebral palsy: recommendations from a consensus conference. NeuroRehabilitation, 2011, vol. 28, no. 1, pp. 37-46. DOI: 10.3233/NRE-2011-0630.

25.Willoughby K., Ang S.G., Thomason P., Graham H.K. The impact of botulinum toxin A and abduction bracing on long-term hip development in children with cerebral palsy. Dev. Med. Child. Neurol., 2012, vol. 54, no. 8, pp. 743-747. DOI:10.1111/j.14698749.2012.04340.x.

26.Shore B.J., Yu X., Desai S., Selber P., Wolfe R., Graham H.K. Adductor surgery to prevent hip displacement in children with cerebral palsy: the predictive role of the Gross Motor Function Classification System. J. Bone Joint Surg. Am., 2012, vol. 94, no. 4, pp. 326-334. DOI: 10.2106/JBJS.J.02003. 
Benij Ortopedii, Vol. 26, no 1, 2020

27.Palisano R.J., Shimmell L.J., Stewart D., Lawless J.J., Rosenbaum P.L., Russell D.J. Mobility experiences of adolescents with cerebral palsy. Phys. Occup. Ther. Pediatr., 2009, vol. 29, no. 2, pp. 133-153. DOI: 10.1080/01942630902784746.

28.Pountney T.E., Mandy A., Green E., Gard P.R. Hip subluxation and dislocation in cerebral palsy - a prospective study on the effectiveness of postural management programmes. Physiother. Res. Int., 2009, vol. 14, no. 2, pp. 116-127. DOI:10.1002/pri.434.

29.Hill S., Goldsmith L. Mobility, posture and comfort. Pawlyn J., Carnaby S., eds. Profound intellectual and multiple disabilities: nursing complex needs. Oxford, UK, Wiley-Blackwell, 2009, ch. 17, pp. 328.

Received: 26.06.2019

\section{Information about the authors:}

1.Elnur I. Dzhomardly,

Federal Scientific Center of Rehabilitation of the Disabled named after G.A. Albrecht, Saint Petersburg, Russian Federation, Email: mamedov.ie@yandex.ru,

ORCID: https://orcid.org/0000-0002-0281-3262

2. Andrei A. Koltsov, M.D., Ph.D.,

Federal Scientific Center of Rehabilitation of the Disabled named after G.A. Albrecht, Saint Petersburg, Russian Federation, Email: katandr2007@yandex.ru, ORCID: https://orcid.org/0000-0002-0862-8826 